\title{
Substitution of Mulberry Leaf Meal on Feed Intake, Body Weight and Carcass Characteristics of Tigray Highland Lambs
}

\author{
Tesfay $\mathrm{G}^{1}$, Tamir $\mathrm{B}^{2}$, Berhane $\mathrm{G}^{2}$ \\ ${ }^{1}$ Department of Animal Production and Technology, Adigrat University, P.O.Box 50, Tigray, Ethiopia \\ ${ }^{2}$ Department of Animal Production Studies, Addis Ababa University, P.O.Box 34, Bishoftu, Ethiopia \\ E-mail: gebrekidan.tes@gmail.com
}

(received 12-01-2017; revised 26-03-2017; accepted 27-03-2017)

\begin{abstract}
ABSTRAK
Tesfay G, Tamir B, Berhane G. 2018. Substitusi tepung daun mulberry terhadap konsumsi pakan, bobot badan dan karakteristik karkas anak domba dataran tinggi Tigray. JITV 23(1): 28-37. DOI: http://dx.doi.org/10.14334/jitv.v23i1.1634

Tujuan dari penelitian ini adalah untuk mengevaluasi pengaruh substitusi tepung daun mulberry sebagian maupun penuh sebagai campuran konsentrat terhadap performa anak domba dataran tinggi Tigray. Sebanyak tiga puluh ekor anak domba jantan dataran tinggi Tigray berumur satu tahun (rata-rata bobot badan 17,8 $\pm 0.95 \mathrm{~kg}$ ) dikelompokkan ke dalam 6 kelompok berdasarkan bobot hidup yang diberikan 5 jenis perlakuan pakan (RCBD), yaitu T1: $300 \mathrm{~g}$ campuran konsentrat tunggal; T2: 225 g campuran konsentrat $+86,55 \mathrm{~g}$ daun mulberry; T3: $150 \mathrm{~g}$ campuran konsentrat $+173,1 \mathrm{~g}$ daun mulberry; T4: $75 \mathrm{~g}$ campuran konsentrat $+259,7 \mathrm{~g}$ daun mulberry; dan T5: 346,2 g daun mulberry tunggal. Perlakuan pakan tersebut dikondisikan sebagaimana mungkin untuk menggantikan campuran konsentrat dengan tepung daun mulberry secara perlahan dari $0 \%$ hingga $100 \%$ dalam kondisi iso-nitrogenous. Anak domba diadaptasikan pada pakan percobaan selama 15 hari dan setelah itu dilakukan percobaan pemberian pakan. Hasil pengamatan menunjukkan bahwa penggantian penuh campuran konsentrat dengan tepung daun mulberry memiliki nilai total konsumsi bahan kering, bahan organik, NDF dan ADF yang lebih tinggi $(\mathrm{P}<0,05)$ dibandingkan dengan pemberian campuran konsentrat tunggal. Parameter performa pertumbuhan sebanding pada semua perlakuan pakan. Bobot potong dan bobot tanpa jeroan pada pemberian pakan tepung daun mulberry tunggal lebih besar $(\mathrm{P}<0,05)$ dibandingkan dengan perlakuan pemberian campuran konsentrat secara penuh. Dengan kata lain, persentase karkas terhadap bobot badan tanpa jeroan dasar dan bobot carcas panas tidak berbeda $(\mathrm{P}>0,05)$ pada perlakuan yang berbeda. Oleh karena itu, daun mulberry dapat berpotensi digunakan untuk penggantian campuran konsentrat sebagai suplemen pakan untuk peternak skala kecil di Ethiopia.
\end{abstract}

Kata Kunci: Daun Mulberry, Daya Cerna, Pertambahan Bobot Badan

\section{ABSTRACT}

Tesfay G, Tamir B, Berhane G. 2018. Substitution of mulberry leaf meal on feed intake, body weight and carcass characteristics of Tigray highland lambs. JITV 23(1): 28-37. DOI: http://dx.doi.org/10.14334/jitv.v23i1.1634

The purpose of this study is to evaluate effects of partial or full substitution of mulberry leaf meal for concentrate mix on performances of Tigray highland lambs. Thirty intact yearlings Tigray highland male lambs (average initial body weights of $17.8 \pm 0.95 \mathrm{~kg}$ ) were separated into 6 groups based on their live weight with each groups assigned 5 treatment diets (RCBD), that are: T1: $300 \mathrm{~g}$ concentrate mix alone, T2: $225 \mathrm{~g}$ concentrate mix $+86.55 \mathrm{~g}$ mulberry leaf, T3: $150 \mathrm{~g}$ concentrate mix $+173.1 \mathrm{~g}$ mulberry leaf, T4: $75 \mathrm{~g}$ concentrate mix $+259.7 \mathrm{~g}$ mulberry leaf and T5: $346.2 \mathrm{~g}$ mulberry leaf alone. The treatments diets were designed in such a way that concentrate mix was progressively replaced by mulberry leaf meal from $0 \%$ to $100 \%$ at isonitrogenous level. Lambs were adapted to experimental diets for 15 days, and after adaptation period, feeding trial was conducted. Results reveal that complete substitution of concentrate mix by mulberry leaf meal showed in higher $(\mathrm{P}<0.05)$ total dry matter, organic matter, NDF and ADF intake than the sole concentrate mix. The growth performance parameters resulted comparable across all the treatment diets. The slaughter weight and empty weight resulted higher $(\mathrm{P}<0.05)$ in sole mulberry leaf meal as compared to the whole concentrate mix supplemented lambs. On the other hand, the dressing percentage on empty body weight base and hot carcass weight showed less difference $(\mathrm{P}>0.05)$ across the different treatments. Therefore, mulberry foliage could potentially be used to replace concentrate mix as a feed supplement for the small holder farmers in Ethiopia.

Key Words: Mulberry Leaf, Digestibily, Weight Gain

\section{INTRODUCTION}

In Ethiopia sheep accounted 34\% of the live animal exports (Gizaw et al. 2013). Moreover, sheep and goats contributed $86 \%$ of the total value of meat exports
(Legese \& Fadiga 2014). Even though the sheep population provided considerable roles to both smallholder farmers and the country's economy but their present contribution is far below their potential. This is due to the quantity and quality of feed resources 
available and feeding systems employed which have great impact on their production and productivity. In areas where livestock are closely integrated with crop production, crop residues are considered as valuable sources of ruminant feeds. The tendency of increased acreage of cropping land is always at the expenses of decreased available grazing lands, thus boost the importance of crop residues as animal feed resources. However, crop residues are of generally low in nutritive value and are fibrous having low digestible organic matter (OM) per kg dry matter (DM)) and low crude protein (CP) content (Tolera 2008); Gizaw et al. 2010).

The increasing pressure on land and the growing demand for livestock products makes it crucial to ensure the effective use of feed resources, including crop residues and other agro-industrial by-products. With the increasing need of human population for animal products, there is a need of matching feed resources available with animal nutrient requirements. Thus, supplementation of crop residues with agroindustrial by-products and/or plant protein sources will alleviate CP deficiency in fibrous feeds (Solomon 2001).

The commercial protein supplements are however, inaccessible and if any too expensive for the small scale farmers. Different studies indicated that mulberry is well comparable with leguminous multipurpose trees and concentrates as a feed for ruminants (Benavides et al. 2000; Sanchez 2002; Cuong et al. 2007; Kabi \& Bareeba 2008; Kandylis et al. 2009). Habib et al. (2016) evaluated the chemical composition of dried mulberry leaves and reported that it has comparable nutrient composition with that of commercial concentrates diets. However, the information on the feeding value of mulberry foliage and its concomitant effect on feed intake, weight gain and carcass characteristics of lambs in Ethiopia are scanty and need further documentation. To this end (FAO 2002) suggested that the urgent need of the farmers for high quality feed for ruminants in developing countries can be achievable through intensive utilization of multipurpose trees and shrubs as they have better nutritional quality nearly equivalent to grain based concentrates.

According to Shayo (1998), leaves of multipurpose trees like mulberry are highly digestible (82\%); contain high concentration of CP $(18.6 \%)$ and mineral matters (14.3), and low cell wall contents. This important characteristic of mulberry foliage is a key attribute that makes it worthy of investigation as feed alternative for ruminants. Nevertheless, there are very limited research reports on the use of mulberry for small ruminants in Ethiopia. Therefore, this study was carried out with the objective of investigating the effect of partial or full substitution of mulberry foliage for concentrate mix on performance of yearling Tigray highland sheep fed barley straw basal diet.

\section{MATERIALS AND METHODS}

\section{Experimental animals, experimental design, treatments and feed intake}

Thirty intact yearlings Tigray highland male lambs with average initial body weights of $17.8 \pm 0.95 \mathrm{~kg}$ having relatively similar body condition were used for the study. The sheep were quarantined, drenched against internal parasites, sprayed for ecto-parasites and vaccinated for anthrax as well as ovine pasteurellosis. They were adapted to experimental feeds for 15 days followed by 90 days of feeding period to determine effect on feed intake and carcass parameters. The supplements were offered in two equal portions at 08:00 and 16:00 hours daily while the water and mineral salt licks were accessed freely to all lambs.

A complete randomized blocked design with five treatments of six animals each was employed and sheep were blocked on the basis of their initial body weight (overnight fasting) and the five treatments were randomly assigned to animals in the block. Lambs were housed in concrete floor that penned individually. The sheep were allocated to the diet groups where concentrate mix was progressively replaced by mulberry leaf meal from $0 \%$ to $100 \%$ at iso-nitrogenous level. The treatments were $300 \mathrm{~g}$ concentrate mix alone, $225 \mathrm{~g}$ concentrate mix $+86.55 \mathrm{~g}$ mulberry leaf, $150 \mathrm{~g}$ concentrate $\operatorname{mix}+173.1 \mathrm{~g}$ mulberry leaf, $75 \mathrm{~g}$ concentrate mix +259.7 g mulberry leaf and $346.2 \mathrm{~g}$ mulberry leaf alone with barley straw ad libitum to all treatments. The concentrate mix contained noug seed cake (NSC) and wheat bran (WB) at ratio of 1:2. Leaves from white mulberry (Morus alba) that was harvested from nearby farmers and nursery areas was collected and dried under a shade for 4-5 days till the leaves were easily crushed when pressed in a hand and was packed in a sack for later use. Feeds offered to experimental sheep and corresponding refusals were weighed and recorded daily throughout the experimental period to determine daily feed intake of experimental sheep. Samples of refusals collected from individual animals every day were pooled over the entire experimental period and sub-sampled for chemical analysis. Experimental animals were weighed on the first day of the feeding trial and subsequently at weekly intervals before offering the morning feed on the same day of the week after withholding feed and water overnight. The average daily body weight gain during the experimental period was calculated by regressing body weight of each animal on number of feeding days. 
Table 1. Chemical composition of feeds used for the experiment

\begin{tabular}{lccccccccc}
\hline \multirow{2}{*}{ Experimental feeds } & \multirow{2}{*}{ DM (\%) } & \multicolumn{7}{c}{ Chemical composition (\%DM) } \\
\cline { 3 - 9 } & & OM & Ash & CP & NDF & ADF & ADL & EE & CF \\
\hline Barley straw & 96.0 & 92.5 & 7.5 & 4.0 & 78.6 & 49.6 & 8.6 & 1.3 & 57.6 \\
Concentrate mix & 90.2 & 92.3 & 7.66 & 22.0 & 35.2 & 20.2 & 3.39 & 7.16 & 13.3 \\
Mulberry leaf meal & 91.8 & 84.3 & 15.7 & 18.5 & 38.0 & 22.3 & 4.19 & 4.15 & 14.2 \\
\hline
\end{tabular}

DM: Dry matter

OM: Organic matter

CP: Crude protein

NDF: Neutral detergent fiber

\section{Digestibility trial}

After completion of 90 days of feeding trial, all animals were fitted with feces collection bag for in vivo digestibility test. The sheep were assigned to the same treatment diet they were offered in the feeding trial. After allowing the animals an adjustment period of three days to the feces collection harness, feces were collected for seven days. Each day's fecal output was weighed and $25 \%$ of it was frozen $\left(-20^{\circ} \mathrm{C}\right)$ in containers meant for individual sheep and the seven days collection were pooled. The same was done for the feed offered and refusal samples collected. Composite samples of feed offered and refused and feces excreted were thawed to room temperature, mixed thoroughly and oven dried at $60{ }^{\circ} \mathrm{C}$ overnight. The dried samples of feeds and feces were ground to pass through $1 \mathrm{~mm}$ sieve and stored in airtight polyethylene containers until analyzed. Nutrient digestibility (\%) was calculated as a difference between nutrient intake and nutrient voided in the feces divided by nutrient intake and the quotient multiplied by 100 .

\section{Chemical analysis of feed offered and refused}

Chemical compositions of the feed and refusal samples were determined at Holeta Agricultural Research Center, Animal Nutrition Laboratory, Ethiopia. Samples of partially dried feeds and refusals were dried overnight at $105^{\circ} \mathrm{C}$ in a forced draft oven for determination of total dry matter content. Samples were analyzed for DM, ash, and nitrogen (N) using the procedure of AOAC (1990) and crude protein (CP) was calculated as $\mathrm{N} \times$ 6.25. Neutral detergent fiber (NDF), acid detergent fiber (ADF) and acid detergent lignin (ADL) were analyzed using the procedures of Van Soest et al. (1991). According to AFRC (1993), ME = $0.16 *$ DOMD, DOMD $=($ Feed OM-Faeces OM $) /$ Feed $\mathrm{DM}$, where DOMD is digestible organic matter in dry matter.

\section{Carcass evaluation}

At the end of feeding trial, all experimental sheep were slaughtered after overnight fasting for evaluation of carcass parameters. Empty body weight was calculated as slaughter weight less gut content. Hot carcass weight was estimated after removing weight of the head, skin, thoracic, abdominal and pelvic cavity contents, and the limbs. Dressing percentage was calculated as a ratio of hot carcass weight and slaughter weight or empty body weight basis. The rib eye muscle area is determined by measuring area of the Longissimus dorsi muscle exposed by cutting the carcass between the $12^{\text {th }}$ and $13^{\text {th }}$ ribs (O'Rourke et al. 2004).

\section{Statistical analysis}

Data from the experiment were subjected to the analysis of variance (ANOVA) in a randomized complete block design using the general linear model procedure of SAS (2008). Individual differences between means were tested using Tukey HSD test. In all the comparisons, the level of significance was set at $\alpha=0.05$.

\section{RESULTS AND DISCUSSION}

\section{Dry matter and nutrient intake}

Results of mean daily dry matter and nutrient intake of different proportions of concentrate to mulberry leaf meal, sole concentrate mix as well as sole mulberry leaf meal fed to the experimental sheep are given in Table 2. All lambs had a complete consumption of the supplemented mulberry and concentrate mix offered. Increasing the substitution rate of concentrate mix by mulberry leaf meal improved $(\mathrm{P}<0.05)$ the dry matter intake of lambs.

Total dry matter intake declined $(\mathrm{P}<0.05)$ when the proportion of mulberry leaf meal in the diet was decreased, and was lowest when an all concentrate diet was fed. Complete substitution of concentrate mix by mulberry leaf meal resulted in higher $(\mathrm{P}<0.05)$ total dry matter intake than those supplemented with whole concentrate mixtures. 
Table 2. Daily intakes of Tigray highland lambs supplemented with graded levels of mulberry leaf meal and concentrate mix

\begin{tabular}{|c|c|c|c|c|c|c|c|}
\hline \multirow{2}{*}{ Intake } & \multicolumn{5}{|c|}{ Treatments } & \multirow[b]{2}{*}{ SEM } & \multirow[b]{2}{*}{ SL } \\
\hline & $\mathrm{T} 1$ & $\mathrm{~T} 2$ & $\mathrm{~T} 3$ & $\mathrm{~T} 4$ & $\mathrm{~T} 5$ & & \\
\hline \multicolumn{8}{|l|}{ Dry matter } \\
\hline Barley straw (g/day) & 539 & 548 & 539 & 551 & 566 & 12.6 & 0.248 \\
\hline CM (g/day) & 300 & 225 & 150 & 75 & & - & - \\
\hline MLM (g/day) & - & 86.6 & 173 & 260 & 346 & - & - \\
\hline TDM (g/day) & $839^{\mathrm{c}}$ & $859^{\mathrm{bc}}$ & $863^{\mathrm{bc}}$ & $886^{\mathrm{ab}}$ & $912^{\mathrm{a}}$ & 12.6 & 0.0002 \\
\hline \multicolumn{8}{|l|}{ Nutrients } \\
\hline $\mathrm{OM}$ (g/day) & $776^{\mathrm{b}}$ & $787^{\mathrm{ab}}$ & $783^{\mathrm{ab}}$ & $798^{\mathrm{ab}}$ & $815^{\mathrm{a}}$ & 11.7 & 0.0282 \\
\hline $\mathrm{CP}$ (g/day) & 87.7 & 87.5 & 86.6 & 86.6 & 86.6 & 0.51 & 0.115 \\
\hline $\mathrm{EE}$ (g/day) & $28.5^{\mathrm{a}}$ & $26.8^{\mathrm{b}}$ & $24.9^{\mathrm{c}}$ & $23.3^{d}$ & $21.7^{\mathrm{e}}$ & 0.16 & $<.0001$ \\
\hline CF (g/day) & $350^{\mathrm{b}}$ & $358^{\mathrm{ab}}$ & $354^{\mathrm{ab}}$ & $364^{\mathrm{ab}}$ & $375^{\mathrm{a}}$ & 5.64 & 0.0131 \\
\hline NDF (g/day) & $529^{\mathrm{c}}$ & $542^{\mathrm{bc}}$ & $543^{b c}$ & $558^{\mathrm{ab}}$ & $576^{\mathrm{a}}$ & 6.78 & 0.0001 \\
\hline $\mathrm{ADF}$ (g/day) & $328^{\mathrm{b}}$ & $336^{\mathrm{b}}$ & $336^{\mathrm{b}}$ & $347^{\mathrm{ab}}$ & $358^{\mathrm{a}}$ & 6.27 & 0.0014 \\
\hline ME (MJ/day) & $8.51^{\mathrm{b}}$ & $8.77^{\mathrm{ab}}$ & $8.70^{\mathrm{ab}}$ & $8.97^{\mathrm{ab}}$ & $9.28^{\mathrm{a}}$ & 0.20 & 0.0099 \\
\hline
\end{tabular}

${ }^{\mathrm{a}-\mathrm{e}}$ Means with different superscript letters in a row differ significantly.

SEM: standard error of the mean; SL: significant level; DM: dry matter; TDM: total dry matter; CM: concentrate mix;

MLM: mulberry leaf meal; OM: organic matter; CP: crude protein; CF: crude fiber; EE: Crude fat; NDF: neutral detergent fiber;

ADF: acid detergent fiber; ME: Metabolisable energy

T1: 300 g concentrate mix + ad libitum barley straw;

$\mathrm{T} 2: 225 \mathrm{~g}$ concentrate mix $+86.55 \mathrm{~g}$ mulberry leaf meal+ad libitum barley straw

T3: 150 g concentrate mix +173.1 g mulberry leaf meal+ ad libitum barley straw;

T4: 75 g concentrate mix +259.7 g mulberry leaf meal+ ad libitum barley straw;

T5: 346MLM: ad libitum barley straw $+346.2 \mathrm{~g}$ mulberry leaf meal

The organic matter intake was higher $(\mathrm{P}<0.05)$ in the diet containing sole mulberry leaf meal than concentrate mix alone. However, there was no difference $(\mathrm{P}>0.05)$ in organic matter intake among $\mathrm{T} 2$, $\mathrm{T} 3, \mathrm{~T} 4$ and $\mathrm{T} 5$ as well as among $\mathrm{T} 1, \mathrm{~T} 2, \mathrm{~T} 3$ and $\mathrm{T} 4$. Organic matter intake was lowest when an all concentrate diet was fed. The supplemented feeds were iso-nitrogenous and this was confirmed by the similar total CP intake of the lambs across the different treatment diets. The NDF and ADF intake was higher $(\mathrm{P}<0.05)$ in the diets containing sole mulberry leaf meal (T5) than T1, T2 and T3. In general, except CP intake that resulted less difference across the different treatments, other nutrients intake showed higher $(\mathrm{P}<0.05)$ in sole mulberry leaf meal than that of the whole concentrate mix.

\section{Apparent dry matter and nutrient digestibility}

Apparent DM, OM, CP, NDF and ADF digestibility were $(\mathrm{P}<0.05)$ affected by treatment effects (Table 3$)$. The apparent DM and OM digestibility was higher $(\mathrm{P}<0.05)$ in sole mulberry than that of full concentrate diet. Except $\mathrm{T} 1$ and T5, the other treatment diets showed no $(\mathrm{P}>0.05)$ difference in apparent $\mathrm{DM}$ and $\mathrm{OM}$ digestibility. A higher $(\mathrm{p}<0.05)$ apparent NDF digestibility was obtained when larger proportion of concentrate mixture was substituted by mulberry leaf meal than the other treatment diets.

\section{Live weight change and feed conversion efficiency}

The final body weights of lambs supplemented with $\mathrm{T} 3$ and T4 concentrate mix as well as T5 had $(\mathrm{p}<0.05)$ higher than those of sheep supplemented with T1 and T2 (Table 4). However, sheep supplemented with T3 and $\mathrm{T} 4$ concentrate mix as well as T5 showed no difference in body weight change but $\mathrm{T} 3$ had significantly $(\mathrm{p}<0.05)$ higher body weight change than those of lambs supplemented with $\mathrm{T} 1$ and $\mathrm{T} 2$. The lambs that were fed with $\mathrm{T} 3$ showed higher $(\mathrm{P}<0.05)$ average daily weight gain (76.9 g/day) than $\mathrm{T} 1$ but no difference with remaining groups. Similarly, feed conversion efficiency (89g gain per gram fed) was also significantly higher $(\mathrm{P}<0.01)$ for lambs that were fed $\mathrm{T} 3$ than those fed with $\mathrm{T} 1$ and T2. In general, all the experimental lambs showed good growth performances throughout the experimental period. 
Tesfay et al. Substitution of mulberry leaf meal on feed intake, body weight and carcass characteristics of Tigray highland lambs

Table 3 Dry matter and nutrient digestibility of the different treatment diets

\begin{tabular}{|c|c|c|c|c|c|c|c|}
\hline \multirow{2}{*}{ Digestibility } & \multicolumn{5}{|c|}{ Treatments } & \multirow{2}{*}{ SEM } & \multirow{2}{*}{ SL } \\
\hline & $\mathrm{T} 1$ & $\mathrm{~T} 2$ & $\mathrm{~T} 3$ & $\mathrm{~T} 4$ & T5 & & \\
\hline DM & $0.668^{\mathrm{b}}$ & $0.680^{\mathrm{ab}}$ & $0.677^{\mathrm{ab}}$ & $0.685^{\mathrm{ab}}$ & $0.695^{\mathrm{a}}$ & 0.007 & 0.0117 \\
\hline $\mathrm{OM}$ & $0.685^{\mathrm{b}}$ & $0.696^{\mathrm{ab}}$ & $0.694^{\mathrm{ab}}$ & $0.703^{\mathrm{ab}}$ & $0.711^{\mathrm{a}}$ & 0.007 & 0.0121 \\
\hline $\mathrm{CP}$ & $0.738^{\mathrm{a}}$ & $0.728^{\mathrm{ab}}$ & $0.721^{\mathrm{b}}$ & $0.721^{\mathrm{b}}$ & $0.725^{\mathrm{ab}}$ & 0.005 & 0.0081 \\
\hline NDF & $0.734^{c}$ & $0.750^{\mathrm{bc}}$ & $0.752^{\mathrm{b}}$ & $0.772^{\mathrm{a}}$ & $0.774^{\mathrm{a}}$ & 0.006 & $<.0001$ \\
\hline $\mathrm{ADF}$ & $0.798^{\mathrm{c}}$ & $0.813^{\mathrm{ab}}$ & $0.794^{c}$ & $0.806^{\mathrm{bc}}$ & $0.823^{\mathrm{a}}$ & 0.005 & $<.0001$ \\
\hline
\end{tabular}

${ }^{\mathrm{a}-\mathrm{c}}$ Means in the same row with different superscript differ significantly; DM : dry matter; OM : organic matter; CP: crude protein;

NDF: neutral detergent fiber; ADF: acid detergent fiber;

T1: barley straw ad libitum $+300 \mathrm{~g} \mathrm{CM}$;

T2: barley straw ad libitum $+225 \mathrm{~g} \mathrm{CM}+86.55 \mathrm{~g}$ MLM;

T3: barley straw ad libitum + 150g CM + 173.1g MLM;

T4: barley straw ad libitum + 75g CM + 259.7g MLM;

T5: barley straw ad libitum +346.2g MLM;

SEM: standard error of mean and SL: level of significance

Table 4 Growth performance parameters of lambs fed on partial or full substituted concentrate mix by mulberry leaf meal

\begin{tabular}{|c|c|c|c|c|c|c|c|}
\hline \multirow{2}{*}{ Growth performance parameters } & \multicolumn{5}{|c|}{ Treatments } & \multirow{2}{*}{ SEM } & \multirow{2}{*}{ SL } \\
\hline & $\mathrm{T} 1$ & $\mathrm{~T} 2$ & $\mathrm{~T} 3$ & $\mathrm{~T} 4$ & T5 & & \\
\hline Initial body weight (kg) & 17.5 & 17.8 & 17.8 & 17.8 & 18.0 & 0.59 & 0.940 \\
\hline Final body weight (kg) & $23.2^{\mathrm{b}}$ & $23.6^{\mathrm{b}}$ & $24.7^{\mathrm{a}}$ & $24.6^{\mathrm{a}}$ & $24.5^{\mathrm{a}}$ & 0.42 & 0.005 \\
\hline Body weight change (kg) & $5.7^{\mathrm{b}}$ & $5.8^{\mathrm{b}}$ & $6.9^{\mathrm{a}}$ & $6.8^{\mathrm{ab}}$ & $6.5^{\mathrm{ab}}$ & 0.39 & 0.012 \\
\hline Average daily weight gain (g/day) & $63.0^{\mathrm{b}}$ & $64.8^{\mathrm{ab}}$ & $76.9^{\mathrm{a}}$ & $75.0^{\mathrm{ab}}$ & $72.2^{\mathrm{ab}}$ & 4.28 & 0.012 \\
\hline Feed conversion efficiency (g gain/g fed) & $0.075^{\mathrm{b}}$ & $0.075^{\mathrm{b}}$ & $0.089^{\mathrm{a}}$ & $0.085^{\mathrm{ab}}$ & $0.079^{\mathrm{ab}}$ & 0.005 & 0.042 \\
\hline
\end{tabular}

${ }^{a-b}$ Means in the same row with different superscript differ significantly;

T1: barley straw ad libitum $+300 \mathrm{~g} \mathrm{CM}$;

$\mathrm{T} 2$ : barley straw ad libitum $+225 \mathrm{~g} \mathrm{CM}+86.55 \mathrm{~g}$ MLM;

T3: barley straw ad libitum + 150g CM + 173.1g MLM

T4: barley straw ad libitum + 75g CM + 259.7g MLM;

T5: barley straw ad libitum +346.2g MLM;

SEM: standard error of mean and SL: level of significance

\section{Effect on main carcass traits}

Carcass characteristics of Tigray highland lambs fed full or partially substituted concentrate mix by mulberry leaf meal were assessed for slaughter weight, empty body weight, hot carcass weight, dressing percentage, rib-eye muscle area and edible and non-edible offal components. The offal components were categorized in to edible (head with tongue, heart, kidney, testis, liver with bile, empty gut, tail and fat from kidney, omentum and heart) and non-edible offal components (skin and legs, penis, lung with trachea, esophagus, spleen, bladder and gut contents) based on the eating habit of the people living around the area where the experiment was conducted.

The slaughter weight, empty body weight and rib eye muscle area indicated higher $(\mathrm{P}<0.05)$ in the sole mulberry leaf meal supplemented groups than those supplemented with concentrate mix alone. Moreover, hot carcass weight indicated significantly $(\mathrm{P}<0.05)$ higher in T3 than T1 and T2. Nevertheless there was less difference among T3, T4 and T5 for hot carcass weight and rib eye muscle area. T3 had higher $(\mathrm{P}<0.05)$ dressing percentage on slaughter weight base as well as empty body weight base than T1 and T2. However, it had less difference with T4 and T5.

\section{Discussions}

\section{Feed intake}

The higher total dry matter intake of sole mulberry leaf meal is in agreement with Van Soest (1994) who noted that improvement in dietary protein supplementation is due to an increase in nitrogen supply to the rumen microorganisms. This leads to an increase 
Table 5. Carcass characteristics of Tigray highland lambs supplemented with graded levels of mulberry leaf meal and concentrate mix

\begin{tabular}{|c|c|c|c|c|c|c|c|}
\hline \multirow{2}{*}{ Parameters } & \multicolumn{5}{|c|}{ Treatments } & \multirow{2}{*}{ SEM } & \multirow{2}{*}{ SL } \\
\hline & $\mathrm{T} 1$ & $\mathrm{~T} 2$ & $\mathrm{~T} 3$ & $\mathrm{~T} 4$ & T5 & & \\
\hline Slaughter weight, $\mathrm{kg}$ & $23.0^{\mathrm{b}}$ & $23.5^{\mathrm{b}}$ & $24.5^{\mathrm{a}}$ & $24.4^{\mathrm{a}}$ & $24.3^{\mathrm{a}}$ & 0.39 & $<.0001$ \\
\hline Empty body weight, kg & $19.3^{\mathrm{b}}$ & $19.8^{\mathrm{b}}$ & $20.7^{\mathrm{a}}$ & $20.5^{\mathrm{a}}$ & $20.5^{\mathrm{a}}$ & 0.36 & $<.0001$ \\
\hline Hot carcass weight, $\mathrm{kg}$ & $10.6^{\mathrm{b}}$ & $10.9^{\mathrm{b}}$ & $11.8^{\mathrm{a}}$ & $11.5^{\mathrm{ab}}$ & $11.5^{\mathrm{ab}}$ & 0.32 & 0.0003 \\
\hline \multicolumn{8}{|l|}{ Dressing percentage on: } \\
\hline Slaughter weight base & $46.1^{\mathrm{b}}$ & $46.4^{\mathrm{b}}$ & $48.0^{\mathrm{a}}$ & $47.1^{\mathrm{ab}}$ & $47.4^{\mathrm{ab}}$ & 0.65 & 0.0087 \\
\hline Empty body weight base & $54.8^{\mathrm{b}}$ & $55.1^{\mathrm{b}}$ & $56.8^{\mathrm{a}}$ & $56.1^{\mathrm{ab}}$ & $56.4^{\mathrm{ab}}$ & 0.65 & 0.0047 \\
\hline Rib eye muscle area, $\mathrm{cm}^{2}$ & $9.0^{\mathrm{b}}$ & $9.3^{\mathrm{b}}$ & $9.9^{\mathrm{a}}$ & $9.8^{\mathrm{a}}$ & $9.6^{\mathrm{a}}$ & 0.18 & $<.0001$ \\
\hline
\end{tabular}

${ }^{\mathrm{a}, \mathrm{b}}$ Means with different superscript letters in a row differ significantly. SEM: standard error of the mean; SL: significant level;

CM: concentrate mix; MLM: mulberry leaf meal;

T1: $300 \mathrm{~g}$ concentrate mix + ad libitum barley straw;

T2: $225 \mathrm{~g}$ concentrate mix $+86.55 \mathrm{~g}$ mulberry leaf meal + ad libitum barley straw

T3: $150 \mathrm{~g}$ concentrate mix $+173.1 \mathrm{~g}$ mulberry leaf meal+ ad libitum barley straw;

T4: $75 \mathrm{~g}$ concentrate mix $+259.7 \mathrm{~g}$ mulberry leaf meal+ ad libitum barley straw;

T5: 346MLM: ad libitum barley straw +346.2 g mulberry leaf meal;

in microbial population and efficiency, thereby enhancing the rate of breakdown of the digesta which eventually leads to increased feed intake. In line with the current study, Atiso et al. (2012) reported that increasing total DM intake with substitution of $50 \%$ of mulberry leaves for concentrate mix compared to sole concentrate mixture supplementation in dairy cows. Nevertheless, Contrary to the present study, (AlpízarNaranjo et al. 2017)reported that the diet supplemented by sole mulberry foliage and that supplemented by whole commercial concentrate showed, respectively, the lower and higher values of total feed intake throughout the whole experimental period.

The increased NDF and ADF intake as the proportion of mulberry leaf meal increases obtained in the current study suggests the relatively increased barley straw intake observed and relatively higher fiber fraction in mulberry than that of the concentrate diet. However, the sole mulberry leaf meal supplemented sheep gained significantly $(\mathrm{P}<0.05)$ higher metabolizable energy than those with whole concentrate diet groups, reflecting higher digestible organic matter consumed by the lambs supplemented with sole mulberry leaf meal. According to Nguyen et al. (2005) and Doran et al. (2007), high nutritive value of mulberry forage have been recognized, and such attributes are sometimes comparable to conventional protein sources used in livestock feeding systems like soybean or alfalfa.

The high nutritive value of mulberry forage and the potential of this excellent alternative protein source forage for animal feeding in the tropics were largely discussed by González-García \& Martín (2016). Mulberry forage banks respond to the objectives of looking for local animal production systems with selfsufficiency in forage production that align with wholefarm systems and address natural resource management issues such as organic matter recycling and other life cycle processes (González-García \& Martín 2016). Moreover, positive animal responses have been obtained across different animal physiological or productive stages, both in meat (beef cattle, sheep and goats) and dairy (cattle, goats) production purposes (González-García \& Martín 2016).

\section{Dry matter and nutrient digestibility}

The significantly $(\mathrm{P}<0.05)$ higher total dry matter intake observed when sole mulberry leaf meal was supplemented might be associated with improved rumen fermentation and rate of digestion without affecting cellulolytic rumen micro-organisms. The increase in intake of feed is in concordance with Van Soest (1994) who noted that improvement in dietary protein supplementation is due to an increase in nitrogen supply to the rumen microorganisms. This leads to an increase in microbial population and efficiency, thereby enhancing the rate of breakdown of the digests which eventually leads to feed intake. Hence, the sole mulberry inclusion improved dry matter intake as compared to the whole concentrates mixture suggesting the potential of mulberry leaf meal in improving intake. The less significance $(\mathrm{P}>0.05)$ difference in apparent digestibility of CP between most of the treatments confirmed the comparable quality of mulberry leaf meal with that of concentrate mixture.

The organic matter digestibility coefficient obtained in the current study conforms to that of Yulistiani et al. 
(2015) and Desta et al. (2017) who have been noted that 0.70 and 0.71 organic matter digestibility coefficients of mature indigenous Malin rams supplemented at $1.2 \%$ of body weight with mixture of mulberry foliage $(50 \%)$ and urea-rice bran $(50 \%)$ and yearling intact male Abergelle sheep respectively. The CP digestibility coefficient obtained in the present study was within the range of values (68.18-76.5\%) for dried mulberry leaves included at different levels in concentrate reported in different literatures (Atiso et al. 2012; T. Desta et al. 2017).

Comparable values to dry matter digestibility coefficient in the present study have been reported for dried mulberry leaves partially substituted lucerne hay and concentrates in Karagouniko sheep breed by Kandylis et al. (2009). Apparent NDF digestibility appears to be positively $(\mathrm{P}<0.05)$ affected by the inclusion of higher proportion mulberry leave meal. This result conforms to Kandylis et al. (2009) who noted due to its high digestibility and excellent level of crude protein, mulberry foliage can be a comparable source to commercial concentrates for ruminant feeding and production.

\section{Body weight gain}

The improved final weight, body weight change and average daily gain when concentrate was partially or fully substituted by mulberry leaf meal were attributed to the differences in digestibility and intake of DM as well as OM observed. Rubanza et al. (2007) also indicated a better growth performance when meals of forage trees like A. nilotica, $A$. polyacantha and $L$. leucocephala were supplemented in combination with other concentrate for goats that is in support of the current finding. Similarly, Alpízar-Narajo et al. (2017) reported that the differences found in dry matter intake could be the indirect resultant of the differences in the energy feed sources offered to each group, i.e. different energy pools coming from concentrate and/or mulberry. In line with the present finding, diet supplementation with mulberry leaves has been reported to lead in increased body weight gains in growing lambs (Benavides et al. 2000) and growing goats (Gonzalez \& Milera 2000). Moreover, Ba et al. (2005) also found that milk production increased with the levels of mulberry offered to goats. Benavides et al. (2000) also observed no difference in milk yield among groups of grazing dairy cattle supplemented with either concentrate or mulberry leaves.

Replacing the mulberry for soybean meal in diets for dairy cows did not affect milk yield or quality (Cuong et al. 2007). Positive results including different levels of mulberry have been reported by others in the feeding of sheep (Pacheco et al. 2002).

\section{Carcass characteristics}

The higher slaughter weight and empty weight resulted in sole mulberry leaf meal as compared to the whole concentrate mix as well as the less differed dressing percentage on empty body weight base and dressed hot carcass weight across the different treatments might justify the potential of mulberry leaf meal to replace partially or fully to the commercial concentrate mixture. Dressing percentage based on empty body weight (54.4-56.8\%) obtained in this study was comparable to 53-56.3\% (Gemechu \& Mekasha 2012), 53-57\% (Legesse 2008) and 55.7-56.4\% (Abreha 2011). However, Gebresilassie (2011) and Gebresilassie (2007) reported lower results of dressing percentage based on empty body $48.6-50 \%$ and $47-53 \%$ respectively, than the current study.

The dressing percentage based on slaughter weight base in the current study ranged between $46.1-48.0 \%$, which seemed in agreement with the $47.3-48.6 \%$ for Tigray highland sheep (Degu et al. 2009). Nevertheless, lower results on dressing percentages of $32-38 \%$, 38$39.6 \%, 39.5-43.4 \%$ and $36-38.4 \%$ on slaughter weight basis than the current study were reported by Gebresilassie (2011) and Mezgebo \& Urge (2011) for local sheep, Gebresilassie (2007) for Arado sheep and Moges (2005) for Wogera sheep, respectively. Generally, the variations in carcass traits in this study and other results of previous studies might be due to variations in age and breed of sheep, and quantity and quality of basal and supplement feeds used during the experiment. In agreement with this, (McDonald et al. 2010) noted that, nutrition, age, sex, genetics, season and other related factors affect the growth and carcass traits of animals.

Rib eye muscle area is an indicator of muscling and amount of lean meat in the carcass. The rib eye muscle area in the current study was in the range of $9.0-9.9 \mathrm{~cm}^{2}$ that is comparable with 8.6-9.5, 6.3-9.2 and 8.2-10.4 $\mathrm{cm}^{2}$ reported by Gemechu \& Mekasha (2012), Degu et al. (2009) and (Legesse 2008) for supplemented groups of Black Head Ogaden sheep, Tigray Highland sheep and Arsi-Bale sheep, respectively. Lower values of rib eye muscle area than the present study were reported by Desta et al. (2017) (8.43-8.98 cm2), Fesaha \& Urge (2014) (6.7-7.3 cm2), Gebresilassie (2011) (4.5-6.5), Abreha (2011) (5.7-6.4 cm2) and Yirga (2008) (7-8.4 $\mathrm{cm} 2$ ) for yearling intact male Abergelle sheep, Black Head Ogaden sheep, local sheep, Tigray Highland sheep and Hararghe Highland sheep, respectively. However, rib eye muscle area in the current study was lower than the values of $13-19.5$ and $11.5-12.75 \mathrm{~cm} 2$ reported by Moges (2005) and Gebresilassie (2007) for supplemented groups of Wogera sheep and Arado sheep, respectively. The differences in rib eye muscle 
area reported by various authors might be due to variations in the amount and quality of supplements and variations in sheep breeds used for the experiment. Rib eye area is affected by the weight and muscularity of the live animal (O'Rourke et al. 2004) and it is increased with carcass weight (Park et al. 2002) and this report conforms to the result of the current finding.

\section{CONCLUSION}

The sole mulberry leaf meal supplementation improved dry matter intake as compared to the whole concentrates mixture suggesting the potential of mulberry leaves in improving intake. Apparent NDF digestibility appears to be positively affected by the inclusion of higher proportion of mulberry leaf meal. The study revealed that supplementing mulberry leaf meal alone to lambs fed based on barley straw could replace concentrate and result in reasonably good performance. The result of the present study also indicated that substitution of mulberry leaf meal for concentrate mixture can be used effectively without affecting the performance of lambs that can be achieved by sole concentrate mixture supplementation.

\section{ACKNOWLEDGMENT}

The author is grateful to ministry of education of Ethiopia and Addis Ababa University for partial financial support for conducting the experiment. All the individuals who made contribution for successful completion of this study were also highly acknowledged.

\section{REFERENCES}

[AFRC] Agricultural Food and Research Council. 1993. Energy and protein requirement of ruminants: An advisory manual prepared by the AFRC technical committee on responses to nutrients. CAB International, Walling-Ford.

[AOAC] Association of Official Analytical Chemist. 1990. Official method of analysis. 12th ed. Washington DC (USA): Association of Official Analytical Chemist.

[FAO] Food and Agriculture Organization. 2002. Animal production based on crop residues: China's experiences. FAO Anim Prod Heal Pap. 149.

[SAS] Statistical Analysis System. 2008. SAS/STAT Guide to personal computers, version 9.2. NC, USA: Statistical Analysis System Institute Inc.
Abreha H. 2011. Effects of supplementation with air dried leaves of African wild olive (Olea africana), red thorn (Acacia lahai) and their mixtures on performance of Tigray highland sheep fed grass hay. Haramaya University Ethiopia.

Alpízar-Naranjo A, Arece-García J, Esperance M, López Y, Molina M, González-García E. 2017. Partial or total replacement of commercial concentrate with on-farmgrown mulberry forage: effects on lamb growth and feeding costs. Trop Anim Health Prod. 49:537-546.

Atiso M, Tesfay Y, Alemayehu T. 2012. Substituting mulberry leaves (Morus indica L.) for concentrate mix in the diet of lactating Holstein Friesian cows. J Dry Lands. 5:372-376.

Ba N, Giang V, Ngoan L. 2005. Ensiling of mulberry foliage (Morus alba) and the nutritive value of mulberry foliage silage for goats in central Vietnam. Livest Res Rural Dev. 17.

Benavides J, Hernandez I, Esquivel J, Vasconcelos J, Gonzalez J, Espinosa E. 2000. Supplementation of grazing dairy cattle with mulberry in Costa Rica. In: Sanchez M, editor. Proceeding Electron Conf Mulberry Anim Prod. Food and Agriculture Organization of the United Nations; p. 147.

Cuong P, Trung N, Cuong V. 2007. Effect of replacement of soybean with mulberry leaves in diets on performance of lactating cows. In: Proc MEKARN Reg Conf 2007 Matching Livest Syst with Available Resour. Halong Bay (Vietnam); p. 25-28.

Degu A, Melaku S, Berhane G. 2009. Supplementation of isonitrogenous oil seed cakes in cactus (Opuntia ficusindica)-tef straw (Eragrostis tef) based feeding of Tigray Highland sheep. Anim Feed Sci Technol. 148:214-116.

Desta T, Yadav R, Teferi A. 2017. Substitution of dried mulberry (Morus indica L.) leaf meal for concentrate mix on feed intake, digestibility, body weight gain and carcass characteristics of Abergelle sheep. Int J Livest Prod. 8:48-56.

Desta TG, Yadav RK, Teferi AT. 2017. Substitution of dried mulberry (Morus indica L.) leaf meal for concentrate mix on feed intake, digestibility, body weight gain and carcass characteristics of Abergelle sheep. Int J Livest Prod. 8:48-56.

Doran M, Laca E, Sainz R. 2007. Total tract and rumen digestibility of mulberry foliage (Morus alba), alfalfa hay and oat hay in sheep. Anim Feed Sci Technol. 138:239-253.

Fesaha G, Urge M. 2014. Comparison of supplementing urea molasses and urea Atella blocks on feed intake, digestibility, body weight change and carcass characteristics of male Black Head Ogaden sheep fed natural pasture hay. J Biol Agric Healthc. 4. 
Gebresilassie N. 2011. Effect of supplementation with dried leaves of Acacia Albida, Acacia seyal and their mixture on feed intake, digestibility, live weight gain and carcass characteristics of local sheep fed barley straw as basal diet. Haramaya University Ethiopia.

Gebresilassie Z. 2007. The effect of supplementation with sesame seed (Sesame indicum) cake, wheat bran, and their mixtures on feed utilization and live weight gain of Arado sheep. Haramaya University Ethiopia.

Gemechu A, Mekasha Y. 2012. Effect of supplementation with graded levels of concentrate mix on feed intake, digestibility, body weight change, carcass parameters and economic benefit of Arsi-Bale sheep fed a basal diet of urea treated barley straw. Haramaya University Ethiopia.

Gizaw S, Abegaz S, Rischkowsky B, Haile A, Mwai AO, Dessie T. 2013. Review of sheep research and development projects in Ethiopia. Nairobi (Kenya).

Gizaw S, Tegegne A, Gebremedhin B, Hoekstra D. 2010. Sheep and goat production and marketing systems in Ethiopia: Characteristics and strategies for improvement. IPMS (Impr. Nairobi, Kenya: International Livestock Research Institute.

González-García E, Martín M. 2016. Biomass yield and nutrient content of a tropical mulberry forage bank: effects of season, harvest frequency and fertilisation rate. Grass Forage Sci. 72:248-260.

Gonzalez E, Milera M. 2000. Mulberry in livestock feeding systems in Cuba: Forage quality and goat growth. Matanzas (Cuba): Food and Agriculture Organization of the United Nations.

Habib G, Khan NA, Sultan A, Ali M. 2016. Nutritive value of common tree leaves for livestock in the semi-arid and arid rangelands of Northern Pakistan. Livest Sci. 184:64-70.

Kabi F, Bareeba F. 2008. Herbage biomass production and nutritive value of mulberry (Morus alba) and Calliandra calothyrsus harvested at different cutting frequencies. Anim Feed Sci Technol. 140:178-190.

Kandylis K, Hadjigeorgiou I, Harizanis P. 2009. The nutritive value of mulberry leaves (Morus alba) as a feed supplement for sheep. Trop Anim Health Prod. 41:1724.

Legese G, Fadiga M. 2014. Small ruminant value chain development in Ethiopia: Situation analysis and trends. Internatio. Nairobi (Kenya): International Livestock Research Institute.

Legesse E. 2008. Supplementation of black head ogaden sheep fed haricot bean (Phaseolus vulgaris) haulms with mixtures of wheat bran and brewers dried grain: Effects on feed utilization, live weight gain and carcass parameters. Haramaya University.
McDonald P, Edwards RA, Greenhalgh JFD, Morgan CA, Sinclair LA, Wilkinson RG. 2010. Animal Nutrition. 7th ed. Harlow (UK): Prentice hall publishing.

Mezgebo G, Urge M. 2011. Effects of Supplementing dried branches of Acacia senegal and cactus cladodes on feed intake, digestibility, body weight gain and carcass characteristics of local male sheep fed barley straw. Haramaya University Ethiopia.

Moges M. 2005. Effect of feeding different levels of breweries' dried grain on live weight and carcass characteristics of Wogera sheep fed on hay basal diet. Haramaya University Ethiopia.

Nguyen X, Giang V, Ngoan L. 2005. Ensiling of mulberry foliage (Morus alba) and the nutritive value of mulberry foliage silage for goats in central Vietnam. Livest Res Rural Dev. 17:1-9.

O'Rourke B, Russell R, Buege D. 2004. Lamb Carcass Evaluation. London (UK): Department of Animal Sciences. University of Wisconsin.

Pacheco D, Lara P, Sanginés R. 2002. Different levels of mulberry (Morus alba) forage in the ration of fattening lambs. In: Proc V Int Work Sylvopastoral Syst First Reg Meet Mulberry, Exp Stn Grass Forages Bind Hatuey. Matanzas (Cuba).

Park GB, Moon SS, Ko YD, Ha JK, Lee JG, Chang HH, Joo ST. 2002. Influence of slaughter weight and sex on yield and quality grades of Hanwoo (Korean native cattle) carcasses. J Anim Sci. 80:129-36.

Rubanza C, Shem M, Bakengesa S, Ichinohe T, Fujihara T. 2007. Effect of Acacia nilotica, A. polyacantha and Leucaena liucocephala leaf meal supplementation on performance of small east African goat fed native pasture hay basal forages. Small Rumin Res. 70:165173.

Sanchez M. 2002. World distribution and utilization of mulberry and its potential for animal feeding. FAO Animal. Rome (Italy): Food and Agriculture Organization.

Shayo C. 1998. Browse leaves and pods as ruminant feed in central Tanzania. Uppsala (Sweden): Swedish University of Agricultural Sciences.

Van Soest P. 1994. Nutritional ecology of the ruminants. 2nd ed. New York (USA): Cornell University Press.

Van Soest P, Robertson B, Lewis B. 1991. Methods for dietary fiber, neutral detergent fiber, and non-starch polysaccharides in relation to animal nutrition. J Dairy Sci. 74:3583-3597.

Solomon M. 2001. Evaluation of selected multi-purpose trees as feed supplements in tef (Eragrostis tef) straw based feeding of Menze sheep. Humboldt University Berlin. 
Tolera A. 2008. Feed resources and feeding management: a manual for feedlot operators and development workers. Washington DC (USA): United State Agency for International Development.

Yirga H. 2008. Supplementation with concentrate mix to Hararghe highland sheep fed a basal diet of urea-treated maize stover: Effect on feed utilization, live weight change and carcass characteristics. Haramaya University Ethiopia.
Yulistiani D, Jelan ZA, Liang JB, Yaakub H, Abdullah N. 2015. Effects of supplementation of mulberry (Morus alba) foliage and urea-rice bran as fermentable energy and protein sources in sheep fed urea-treated rice straw based diet. Asian-Australasian J Anim Sci. 28:494-501. 